\title{
The Effect of Cytotoxic Dose of Diclofenac on APC Gene Expression in Cervical Cancer (Hela) Cell Line
}

\begin{abstract}
Erfani M, Ahmadi R, Farahani N*, Karimi Ghezeli Z
Minoo Erfani is with the Department of Biochemistry, Faculty of Advanced Sciences \& Technology, Pharmaceutical Sciences Branch, Islamic Azad University, Tehran, Iran.(IAUPS) (M.erfani@gmail.com)

Rahim Ahmadi is with the Department of Biology, Faculty of Basic Sciences, Hamedan Branch, Islamic Azad University, Hamedan, Iran (Drrahahmadi@yahoo.com)

Najmaeh Farahani * (Corresponding author) Department of Immunology, Arak University of Medical Sciences, Arak, Iran. (e-mail: N.farahani@yahoo.com).

Zahra Karimi Ghezeli is with the Department of Pharmaceutical Chemistry, Faculty of Pharmaceutical Chemistry, Pharmaceutical Branch, Islamic Azad University, Tehran, Iran (IAUPS)

(e-mail: $\underline{\text { sandrakarimi20@gmail.com) }}$

Abstract: Studies show that diclofenac is effective on cancer. The main aim of this study is to determine the effects of diclofenac on APC gene expression in cervical cancer (HELA) cells in cell culture. In this experimental laboratory study, cervical cancer cells were exposed to 10, 1, 0.1, 0.01, 0.001 and $0.0001 \mathrm{mg} / \mathrm{ml}$ of diclofenac. MTT assay was used to determine cytotoxic effects of diclofenac on Hela cells. APC gene expression was also measured using real time PCR. Finally, the data were analyzed using SPSS 19 software and ANOVA. The results of this research showed that concentrations of $0.1,1$, and $10 \mathrm{mg} / \mathrm{ml}$ of diclofenac had toxic effects on Hela cell line $(P<0.05, P<0.001$ and $P<0.001$, respectively). Using IC50 dose of diclofenac resulted in APC gene expression increase compared with control group $(P<0.05)$. Our findings indicated that cytotoxic dose of diclofenac has increasing effect on APC gene expression level, indicating that has anticancer effects on Hela cells as well.
\end{abstract}

Keywords: Diclofenac, Hela cells, APC Gene.

\section{Introduction}

Diclofenac was first synthesized in the 1960's and is currently available as ophthalmic, oral, parenteral, rectal and skin preparations. Diclofenac as a member of the non-steroidal anti-inflammatory (NSAID) drugs is used for the management of inflammation and pain but it is also used to treat actinic keratosis [1].

The APC gene provides instructions for making the APC protein, which plays a critical role in several cellular processes. The APC protein acts as a tumor suppressor, which means that it keeps cells from growing and dividing too fast or in an uncontrolled way. Close examination of the function of APC has shown that it is a multifunctional protein involved in a wide variety of processes, including regulation of cell proliferation, cell migration, cell adhesion, cytoskeletal reorganization, and chromosomal stability [2].

Cervical cancer is a major gynecological cancer which involves uncontrolled cell division and tissue invasiveness of the female uterine cervix [3]. Epidemiological studies have shown that the regular use of nonsteroidal anti-inflammatory (NSAIDs) drugs is associated with a reduced risk of various cancers [4]. According 
to previous studies reporting the association of diclofenac with cancer cells, we exerted this study to determine the effects of diclofenac on APC gene expression in cervical cancer cells (HELA) in cell culture.

\section{Materials and Methods}

In this experimental laboratory study, cervical cancer (Hela) cells were exposed to 10, 1, 0.1, 0.01, 0.001 and $0.0001 \mathrm{mg} / \mathrm{ml}$ of diclofenac. MTT assay was used to determine cytotoxic effects of diclofenac on Hela cells. APC gene expression was also measured using real time PCR. Finally, the data were analyzed using SPSS 19 software and ANOVA.

\section{Results}

The results of this research showed that concentrations of $0.1,1$, and $10 \mathrm{mg} / \mathrm{ml}$ of diclofenac had toxic effects on Hela cell line $(\mathrm{P}<0.05, \mathrm{P}<0.001$ and $\mathrm{P}<0.001$, respectively). Using IC50 dose of diclofenac resulted in increased APC gene expression level compared with control group $(\mathrm{P}<0.05)$ (Figure 1).

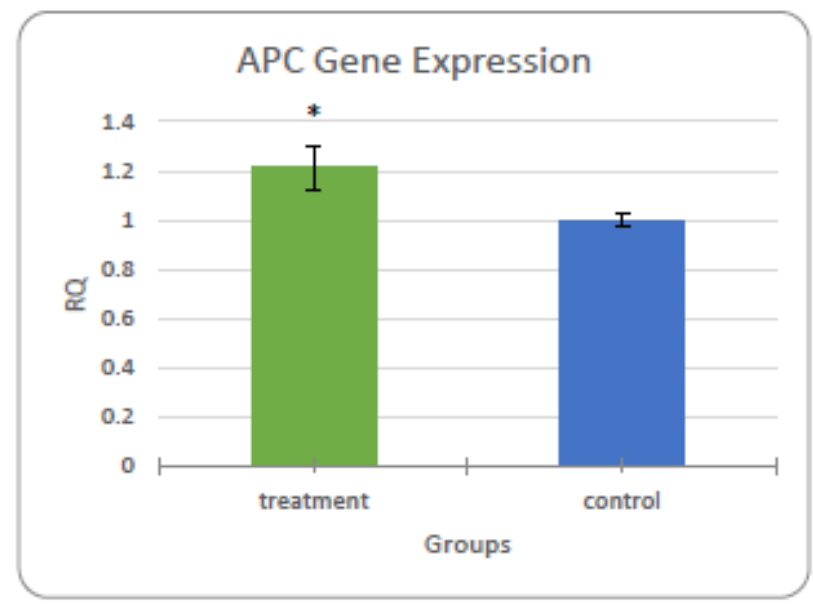

Fig. 1. APC gene expression level in diclofenac receiving Hela cells compared with control group. * indicates significant difference at $\mathrm{P}<0.05$ compared to control group

\section{Discussion}

Our findings indicated that diclofenac has cytotoxic and anticancer effects on cervical cancer cells. In line with our findings it has been shown that non-steroidal anti-inflammatory drugs (NSAIDS) are emerging as a particularly valuable class of drugs due to their recently reported anti-tumoral activity in colorectal cancer[5], [6].

Diclofenac derivatives also inhibit osteoclast formation and suppress breast cancer cells [7]. Studies have shown that diclofenac can induce apoptosis and reduced tumor growth [8]. NSAIDs also may involve in preventing prostate cance in men [9] , [10]. It has been reported that frequent and long-term use of nonsteroidal anti-inflammatory drugs is associated with decreased odds of cervical cancer [11]. Increase in APC expression level also is associated with decreased risk of cancer [12-16].

\section{Conclusion}

Our findings indicated that cytotoxic dose of diclofenac has increasing effect on APC gene expression level, indicating that has anticancer effects on Hela cells as well.

\section{Acknowledgment}

We appreciate all who helped us to exert this study. 


\section{References}

[1] Goh CF, Lane ME.Formulation of diclofenac for dermal delivery. Int J Pharm. 2014;473(1-2):607-16.

[2] van Es JH, Giles RH, Clevers HC.The many faces of the tumor suppressor gene APC. Exp Cell Res. 2001; 264(1):126-34.

[3] Dasari S, Wudayagiri R, Valluru L.Cervical cancer: Biomarkers for diagnosis and treatment. Clin Chim Acta. 2015;445:7-11.

[4] Valle BL, D'Souza T, Becker KG, Wood WH 3rd, Zhang Y, Wersto RP, et al.Non-steroidal anti-inflammatory drugs decrease E2F1 expression and inhibit cell growth in ovarian cancer cells. PLoS One. 2013;8(4):e61836.

[5] Marques JG, Gaspar VM, Costa E, Paquete CM, Correia IJ.Synthesis and characterization of micelles as carriers of non-steroidal anti-inflammatory drugs (NSAID) for application in breast cancer therapy. Colloids Surf B Biointerfaces. 2014;113:375-83. 26.

[6] Kaur J, Sanyal SN.Intrinsic mitochondrial membrane potential change and associated events mediate apoptosis in chemopreventive effect of diclofenac in colon cancer. Oncol Res. 2010;18(10):481-92.

[7] Frantzias J, Logan JG, Mollat P, Sparatore A, Del Soldato P, Ralston SH, et al. Hydrogen sulphide-releasing diclofenac derivatives inhibit breast cancer-induced osteoclastogenesis in vitro and prevent osteolysis ex vivo. $\mathrm{Br} \mathbf{J}$ Pharmacol. 2012;165(6):1914-1925.

[8] Zerbini LF, Tamura RE, Correa RG, Czibere A, Cordeiro J, Bhasin M, et al. Combinatorial effect of non-steroidal anti-inflammatory drugs and NF-kB inhibitors in ovarian cancer therapy. PLoS One. 2011;6(9):e24285.

[9] Doat S, Cénée S, Trétarre B, Rebillard X,Lamy PJ, et al. Nonsteroidal anti-inflammatory drugs (NSAIDs) and prostate cancer risk: results from the EPICAP study. Cancer Med. 2017;6(10):2461-2470.

[10] Daniels NA, Chen YH, Bent S. Antibiotic and anti-inflammatory use and the risk of prostate cancer. BMC Res Notes. 2009;2:57.

[11] Friel G, Liu CS, Kolomeyevskaya NV, Hampras SS, Kruszka B, Schmitt K,et al.Aspirin and Acetaminophen Use and the Risk of Cervical Cancer. J Low Genit Tract Dis. 2015;19(3):189-93.

[12] Narayan S, Jaiswal AS, Law BK, Kamal MA, Sharma AK, Hromas RA.Interaction between APC and Fen1 during breast carcinogenesis. DNA Repair (Amst). 2016;41:54-62

[13] Chen TH, Chang SW, Huang CC, Wang KL, Yeh KT, Liu CN, et al. The prognostic significance of APC gene mutation and miR-21 expression in advanced-stage colorectal cancer. Colorectal Dis. 2013;15(11):1367-74.

[14] Bria E, De Manzoni G, Beghelli S, Tomezzoli A, Barbi S, Di Gregorio C, et al. A clinical-biological risk stratification model for resected gastric cancer: prognostic impact of Her2, Fhit, and APC expression status. Ann Oncol. 2013;24(3):693-701

[15] Olsen AK, Coskun M, Bzorek M, Kristensen MH, Danielsen ET, Jørgensen S. et al. Regulation of APC and AXIN2 expression by intestinal tumor suppressor CDX2 in colon cancercells. Carcinogenesis. 2013;34(6):1361-9.

[16] Song Y, Zhang C.Hydralazine inhibits human cervical cancer cell growth in vitro in association with APC demethylation and re-expression. Cancer Chemother Pharmacol. 2009;63(4):605-13. 